\title{
Pivoting Lean Manufacturing through Industry 4.0 in the Indian Context
}

\author{
Protik Basu ${ }^{1} *$ and Pranab K. Dan ${ }^{2}$ \\ ${ }^{1}$ Army Institute of Management, Judges Court Road, Kolkata, West Bengal, India \\ ${ }^{2}$ Rajendra Mishra School of Engineering Entrepreneurship, Indian Institute of Technology, West Bengal, India \\ *Corresponding Author \\ E-Mail: protik_basu@yahoo.com, pkdan@see.iitkgp.ac.in
}

\begin{abstract}
Industry 4.0 and lean management both focus on increasing productivity of industrial systems. Industry 4.0 is foreseen to revolutionize today's manufacturing environment whereas lean management is an integrated techno-operational system which has gained increasing importance in recent times to bring about a competitive state in an organization. Though in the last three decades there have been rigorous studies on lean manufacturing (LM), its implementation in the Indian manufacturing domain is still in its nascent stage. A lack of research to explore the potential use of Industry 4.0 is also noted. Research work on the compatibility of Industry 4.0 with LM is scarce and any study on the role of Industry 4.0 on LM in the Indian manufacturing sector is practically unavailable. The aim of this research is to explore how the fourth industrial revolution, referred to as Industry 4.0, can strategize LM in the Indian manufacturing context. Empirical studies have disclosed that Indian managers are hesitant to go for automation and technological developments. Results of this work reveal that there needs to be a change in attitude and approach. Lean implementers in India need to embrace Industry 4.0 to pivot LM by automating through CyberPhysical Systems and creating a flexible design and production model of customized and smart products.
\end{abstract}

Keywords:Industry 4.0, Lean Manufacturing, Lean Implementation

\section{INTRODUCTION}

Industry is the part of an economy that produces material goods through processes which are highly mechanized and automated [1]. Global competition in the industry is growing at a more rapid rate and to a greater extent than expected. Lean management is an integrated technooperational system to induce a competitive advantage within an organization. By integrating the physical real world with the information age, the latest trend, viz., Industry 4.0 will lead towards future industrial development. This paper is an attempt to study how lean manufacturing (LM) can be pivoted through Industry 4.0 in the Indian manufacturing sector.

The process of Industrial Revolution began in Britain in the 18th century and from there it has spread to other parts of the world. Although used earlier by French writers, the term Industrial Revolution was first made popular by the English economic historian Arnold Toynbee to describe Britain's economic development from 1760 to 1840 [2]. Since Toynbee's time the term has been more broadly applied and those technological leaps that have led to paradigm shifts, are today termed as "industrial revolutions" [1]. Within the first three industrial revolutions, human civilization has witnessed and created mechanical, electrical and information technology to augment productivity of manufacturing processes [3]. Since the first Industrial Revolution, subsequent revolutions have resulted in radical changes in manufacturing [4]. The first industrial revolution involved the establishment of factories using mechanical machines and steam or water power to move from craft production to industrial manufacturing in the textile industry [5]. Thus it focused on improving the efficiency through the use of hydropower, increased use of steam power and development of machine tools [3]. The second industrial revolution was marked by the replacement of steam by electricity, which resulted in huge developments [6].

The third industrial revolution which started around 1970 [5] further accelerated automation through widespread digitization [1, 3]. It took advantages of developments in information technology and operations research and industries found the use of numerically controlled machines, computer aided engineering, design and manufacturing software, and automated material handling devices and robots. It is within this paradigm of industrial production that lean was born [5]. The term "lean" was coined by Krafcik [7] to denote a production strategy that aims to reduce the usage of resources of all kinds, in contrast to traditional mass production system. Derived originally from the Toyota Production System (TPS), LM helps to make production more controllable by introducing a set of selfregulated principles, tools and techniques [8].

We are now in the beginning of the fourth industrial revolution, commonly referred to as Industry 4.0, which is based on large amount of heterogeneous data and knowledge integration [9]. Recently, the Cyber Physical Systems (CPS) and Internet of Things (IoT) are two stateof-the-art technologies that have progressed. With the development of these technologies, a new concept, Industry 4.0, was introduced in 2011 in Germany, which symbolizes the beginning of the fourth industrial revolution [4]. On the basis of an advanced digitalization within factories, the combination of Internet technologies and future-oriented technologies results in a new fundamental paradigm shift in industrial production [1]. The shop-floor of smart factories will be embedded within the global networks of supply and demand through the cloud. It will be a "self-diagnosing, 
self-optimizing and self-configuring" system [5]. This is supposed to realize the manufacturing of individual products in a batch size of one (the ideal situation of LM) while maintaining the economic conditions of mass production [1]. The term Industry 4.0 is thus established to describe the fourth industrial revolution which, similar to preceding disruptive developments, will change supply chains and business processes significantly [6]. However, unlike the other three industrial revolutions, the fourth industrial revolution is being predicted, therefore allowing companies to take specific actions before it actually takes place [10].

The driving force behind the development of lean management was the elimination of waste, especially in Japan, a country with few natural resources [11]. Again, Industry 4.0 is aimed at making factories more intelligent, flexible and dynamic by equipping manufacturing with sensors and autonomous systems [9]. LM and Industry 4.0 do not eradicate each other; jointly they add more value to the users [12]. Lean principles are likely to become more important in the on-going fourth industrial revolution [5]. Once lean production is conceptualized and implemented, it becomes easier to implement the digitized product lifecycle management and the CPS. On one hand, lean production is the basis of the intelligent manufacturing and lean principles become useful for the implementation of the intelligent manufacturing. On the other hand, the intelligent manufacturing gives the technological support to more efficient and outstanding implementation of lean production [8]. Industry 4.0 technologies may be exactly what are needed to develop and establish lean supply chains and networks [5]. However, Industry 4.0 is presently in its nascent stage and as stated by Schmidt et al. [6], there is a lack of research on the potential use of Industry 4.0. Literature is found to be not yet enriched with journal articles on Industry 4.0 and extant literature on the compatibility and combination of Industry 4.0 and lean is limited.

In this background, this work not only focuses on the interdependence between LM and Industry 4.0 but also attempts to pivot LM strategy through Industry 4.0 in the context of the Indian manufacturing industries. This paper is organized as follows. Sections 2 and 3 introduce the concept of LM and Industry 4.0 respectively. Section 4 enumerates the LM factors affected by Industry 4.0. Managerial implications of the research for the Indian manufacturing sector are discussed subsequently in section 5, followed by the concluding section.

\section{LEAN MANUFACTURING}

The manufacturing era had started with craft manufacturing. Thereafter, there evolved the age of mass production, and, more recently, there is the emergence of the concept of LM to increase productivity and achieve significant improvements in the industry [13]. The roots of Lean Production (LP) have stemmed from the Mass Production
(MP) concepts developed in the US by Henry Ford and other pioneers. Toyota Company and other Japanese automotive plants had to basically make a fresh start during the period after World War II. Taiichi Ohno, Chief Engineer of Toyota had a dislike to all forms of waste, which motivated him to visit a US automotive plant to learn American production methods, thereafter to develop some of the basic concepts and methodologies that have come to be known later as lean production (LP). Therefore Ohno is given the credit for initiating the practices of LP though the term lean production was not used by Taiichi himself [14].

Krafcik [7] first employed the word "Lean" to describe the new production techniques introduced by Taiichi Ohno. Krafcik was studying developments in the automobile industry as a part of the International Motor Vehicle Programme (IMVP), a research project being executed at the Massachusetts Institute of Technology (MIT). The project was undertaken by Daniel Roos, James Womack and Daniel Jones. The work was published in their book, The Machine that Changed the World [15]. Womack and Jones [16] extended the group of techniques pioneered by Toyota into their ideas of Lean Thinking. The term "lean production" is also known as the Toyota Production System (TPS) because of its origins at Toyota Motors [14, 17]. The Lean concept has thus evolved into a managerial philosophy that focuses on eliminating non-value-added activities from the value chain by eliminating different forms of waste [18].

In the past three decades much attention has centred on lean and many researchers have contributed to the definition of LM [19]. Bhamu and Singh Sangwan [20] have provided 33 such definitions of lean in a chronological order, "reflecting the changing goals, principles and scope". Being a multidimensional concept [21], lean includes a variety of management principles and practices under its umbrella. Rigorous academic research has highlighted a broad set of such practices under LM [22] to reduce cost through the persistent removal of wastes and through the simplification of all manufacturing and support processes [23]. Focus is to produce only what is demanded by the customer and only at the necessary time and quantity, thereby eliminating waste and utilizing resources efficiently [24]. The seven typical categories of waste which are to be identified and eliminated are defective units (scrap) or rework, overprocessing, unnecessary motions, overproduction, waiting, unnecessary transportation and excessive inventory. Womack and Jones [16] identified five key principles of the lean organization: the elimination of waste (or muda), the identification of the value stream, the achievement of flow through the process, pacing by a pull (or kanban) signal, and the continuous pursuit of perfection. LM thus provides companies with the tools to survive in a global market that demands higher quality, faster delivery and lower prices.

\section{INDUSTRY 4.0}

In recent years, "Industry 4.0 " is being widely discussed and has become a hotspot for many global industries [3]. The 
main idea of Industry 4.0, as a high-tech strategy for 2020, first appeared as a final report by Kagermann et al. [25] on behalf of a working committee appointed by the German government. In response to the European debt crisis, the German Government presented this strategy to further consolidate and promote global German manufacturing clout. In April 2013, the term "Industry 4.0" re-appeared at an industrial fair in Hannover Germany in the form of a manifesto by the German National Academy of Science and Engineering, and it quickly rose as the German national strategy [26].

Since its first publication, quite a few European manufacturing research organizations and companies have also produced work on this topic, which emphasizes that under Industry 4.0, manufacturing will consist of exchanged information and controlled machines and production units acting autonomously and intelligently [4]. Accordingly, machines and equipment will achieve high levels of selfoptimization and automation. In addition, the manufacturing process will have the capacity of fulfilling more complex and qualified standards and requirements of products. Thus, intelligent factories and smart manufacturing are the major goals of Industry 4.0 [9]. Intelligent production systems and processes as well as suitable engineering methods and tools will be a key factor to successfully implement distributed and interconnected production facilities in future smart factories [27]. Responding to customer demands for tailored products, these smart factories, fuelled by technology enablers such as Internet of Things, Cloud computing, Mobile devices and Big Data, 3D printing, among others, create a totally new environment [10].

Despite of the great interest in the concept of Industry 4.0 worldwide, there is no single accepted definition for it [28]. Industry 4.0 is a complex and flexible system involving digital manufacturing technology, network communication technology, computer technology, automation technology and many other areas. It is expected to increase industrial productivity by $30 \%$ [3] and is further described by three paradigms: the Smart Product, the Smart Machine and the Augmented Operator [29]. The five major features of Industry 4.0 are (i) digitization, optimization, and customization of production; (ii) automation and adaptation; (iii) human machine interaction (HMI); (iv) value-added services and businesses, and (v) automatic data exchange and communication [9]. To achieve more intelligent manufacturing processes, Industry 4.0 relies on CPS and construction of Cyber-Physical Production Systems (CPPS). The concept of CPS was first defined in 2006 by Dr. James Truchard who introduced the fascinating concept that the virtual world and the physical world can be merged by CPS. Industry 4.0 makes use of CPS technology to build a CPPS platform, which connects virtual space with the physical world, to enable equipment in a smart factory to be more intelligent, thus creating better production conditions enabling smart production [3, 10]. Recent advances in manufacturing industry has paved way for a systematical deployment of CPS, within which information from all related perspectives is closely monitored and synchronized between the physical factory floor and the cyber computational space [30].

In a CPPS environment intelligent production systems are linked with one another for easy and fast data exchange [31]. Mobile computing, cloud computing, big data, and the IoT are the key technologies of Industry 4.0. The IoT includes radio frequency identification (RFID) devices, infrared and laser sensors, global positioning systems and other arbitrary objects, which can be connected to the Internet according to an agreed protocol, for information exchange and communication, so as to realize intelligent identification, location, tracking, monitoring and management [3]. Mobile computing and cloud computing provide powerful and accurate data and service for Industry 4.0 by integrating industrial IoT networks. IoT and industry 4.0 will change the relationship among customers and producers. Producing decisions will not be dominated by manufacturers only. Instead, IoT and Industry 4.0 will make customers more involved in decisions about quality and the customization of products [9].

\section{THE INTERSECTION OF LEAN MANUFACTURING AND INDUSTRY 4.0}

The performance of a business is determined by the complex interactions of people, materials, equipment, and resources [11]. While both lean management and Industry 4.0 represent the state-of-the-art, there is an overlap between the operational instruments and concepts between them. In a highly competitive environment, an organization would like to utilize Industry 4.0 to steer LM for its successful implementation. Based on past literature, an attempt has been made to list the LM implementation factors which are directly affected by Industry 4.0. It is also observed from past literature that the common objective of LM and Industry 4.0 is to increase efficiency or productivity of industrial systems.

Table I summarizes those factors which have been categorically mentioned as LM factors in research papers on Industry 4.0. Table 2 lists those factors which are not categorically mentioned as LM factors in research papers on Industry 4.0 but in fact, they are LM factors, according to past literature on LM. \# indicates those factors which appear in both tables.

Based on the number of occurrences, it is observed from Tables I and II that Automation, along with allied technological developments, is the most referred LM factor which is affected by Industry 4.0. This is also quite expected since Industry 4.0 is the fourth industrial revolution which is expected to bring a radical change in the near future. The following section discusses how Industry 4.0 can be utilized by Indian managers to aid LM implementation in order to improve productivity and remain competitive in the global scenario. 
TABLE I INDUSTRY 4.0 AFFECTING LM FACTORS (FACTORS CATEGORICALLy MENTIONED As LM FACTORS)

\begin{tabular}{|l|c|c|c|c|c|c|}
\hline \multicolumn{1}{|c|}{ Factors } & [8] & [12] & [29] & [30] & [32] & [33] \\
\hline 5S methodology & & & & & & $\checkmark$ \\
\hline Automation and technology\# & $\checkmark$ & $\checkmark$ & $\checkmark$ & $\checkmark$ & $\checkmark$ & \\
\hline Continuous flow / JIT $^{\#}$ & $\checkmark$ & $\checkmark$ & $\checkmark$ & & & $\checkmark$ \\
\hline Decentralization $^{\#}$ & $\checkmark$ & $\checkmark$ & $\checkmark$ & & & \\
\hline Employee involvement / Teamwork & $\checkmark$ & & & & & $\checkmark$ \\
\hline Flexibility $^{\#}$ & $\checkmark$ & $\checkmark$ & $\checkmark$ & & & \\
\hline Heijunka & & & & & & $\checkmark$ \\
\hline Jidoka / Andon & & & $\checkmark$ & & & $\checkmark$ \\
\hline Kaizen & & $\checkmark$ & $\checkmark$ & & & $\checkmark$ \\
\hline Maximum resource/asset utilization ${ }^{\#}$ & $\checkmark$ & & & $\checkmark$ & & \\
\hline Modular Production & & $\checkmark$ & & & & \\
\hline Overall Equipment Effectiveness & & & & $\checkmark$ & & \\
\hline Poka yoke & & $\checkmark$ & $\checkmark$ & & & \\
\hline Process control ${ }^{\#}$ & $\checkmark$ & & & $\checkmark$ & & \\
\hline Pull production / Kanban & $\checkmark$ & $\checkmark$ & $\checkmark$ & & & \\
\hline Role of customer ${ }^{\#}$ & $\checkmark$ & & & & & \\
\hline Role of supplier & $\checkmark$ & & & & & \\
\hline Setup time reduction / SMED & $\checkmark$ & $\checkmark$ & $\checkmark$ & & & \\
\hline Standardization & $\checkmark$ & $\checkmark$ & & & & $\checkmark$ \\
\hline Takt time & & & & & & $\checkmark$ \\
\hline Total productive maintenance (TPM) & $\checkmark$ & & & & & \\
\hline Waste reduction & $\checkmark$ & & & $\checkmark$ & & $\checkmark$ \\
\hline
\end{tabular}

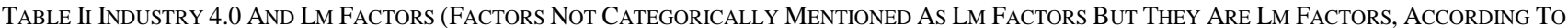
PAST LITERATURE)

\begin{tabular}{|c|c|c|c|c|c|c|c|c|c|c|c|c|c|c|c|c|c|c|c|}
\hline Factors & [3] & [4] & [6] & [9] & [10] & [26] & [27] & [28] & [31] & [34] & [35] & {$[36]$} & [37] & [38] & [39] & [40] & [41] & [42] & [43] \\
\hline $\begin{array}{l}\text { Automation and } \\
\text { technology }\end{array}$ & $\checkmark$ & $\checkmark$ & $\checkmark$ & $\checkmark$ & $\checkmark$ & $\checkmark$ & $\checkmark$ & $\checkmark$ & $\checkmark$ & $\checkmark$ & $\checkmark$ & & $\checkmark$ & $\checkmark$ & $\checkmark$ & $\checkmark$ & & & $\checkmark$ \\
\hline Continuous flow" & & & $\checkmark$ & & $\checkmark$ & $\checkmark$ & & & & & & $\checkmark$ & & & & & & & \\
\hline Culture & & & & & & & & & & $\checkmark$ & & & & & & & & & \\
\hline Decentralization ${ }^{\#}$ & $\checkmark$ & $\checkmark$ & & $\checkmark$ & $\checkmark$ & $\checkmark$ & $\checkmark$ & & & $\checkmark$ & $\checkmark$ & & $\checkmark$ & $\checkmark$ & & $\checkmark$ & & $\checkmark$ & \\
\hline $\begin{array}{l}\begin{array}{l}\text { Efficient } \\
\text { management }\end{array} \\
\end{array}$ & $\checkmark$ & & & & & & & & & $\checkmark$ & & & & & & & & & \\
\hline Flexibility $^{\#}$ & $\checkmark$ & $\checkmark$ & $\checkmark$ & $\checkmark$ & & & $\checkmark$ & $\checkmark$ & $\checkmark$ & & $\checkmark$ & $\checkmark$ & $\checkmark$ & & $\checkmark$ & & $\checkmark$ & $\checkmark$ & \\
\hline Focus on Product & & $\checkmark$ & $\checkmark$ & $\checkmark$ & $\checkmark$ & $\checkmark$ & $\checkmark$ & & & $\checkmark$ & $\checkmark$ & & & & & & & & \\
\hline Leadership & & & & & & & & & & $\checkmark$ & & & & & & & & & \\
\hline $\begin{array}{l}\text { Maintenance / } \\
\text { TPM }^{\#}\end{array}$ & & $\checkmark$ & $\checkmark$ & $\checkmark$ & & & $\checkmark$ & $\checkmark$ & & & $\checkmark$ & & & & & & & & $\checkmark$ \\
\hline Mass customization & $\checkmark$ & $\checkmark$ & $\checkmark$ & $\checkmark$ & $\checkmark$ & $\checkmark$ & $\checkmark$ & $\checkmark$ & & & & & $\checkmark$ & & & & & $\checkmark$ & \\
\hline $\begin{array}{l}\text { Maximum resource } \\
\text { / asset utilization }\end{array}$ & $\checkmark$ & & & $\checkmark$ & & $\checkmark$ & $\checkmark$ & & & & $\checkmark$ & & & & & & & & \\
\hline $\begin{array}{l}\begin{array}{l}\text { Process } \\
\text { management / } \\
\text { control }^{\#}\end{array} \\
\end{array}$ & $\checkmark$ & $\checkmark$ & $\checkmark$ & $\checkmark$ & & $\checkmark$ & & & & & & & & & & & & & \\
\hline $\begin{array}{l}\text { Production time } \\
\text { improvement }\end{array}$ & & & $\checkmark$ & & & & & & & & & & & & & & & & \\
\hline Role of customer ${ }^{\#}$ & & $\checkmark$ & & $\checkmark$ & & $\checkmark$ & $\checkmark$ & $\checkmark$ & & $\checkmark$ & & & & & & & & & \\
\hline $\begin{array}{l}\text { Staff training and } \\
\text { development }\end{array}$ & $\checkmark$ & & & & & $\checkmark$ & & & & & & & & & & & & & \\
\hline Strategy & & & & & & & & & & $\checkmark$ & & & & & & & & & \\
\hline Value Creation & & & $\checkmark$ & $\checkmark$ & & $\checkmark$ & $\checkmark$ & & & & $\checkmark$ & & & & & $\checkmark$ & & & \\
\hline
\end{tabular}




\section{MANAGERIAL IMPLICATIONS FOR INDIAN MANUFACTURING SECTOR}

According to So and Sun [44], technology plays a role in improving the existing manufacturing process and implementing a responsive production system. Cellular manufacturing, depending on Group Technology, is a popular lean tool [45-46] or practice [21]. Success of the cellular layout depends on the successful implementation of the U-shape manufacturing line, multi-skill process knowledge or cross-training of workers and it leads to improved flexibility, productivity, reduced setup time, reduced work-in-process inventory, reduced throughput time, reduced material handling costs, improved product quality and simplified scheduling [47]. Shah and Ward [21] and Shah et al. [22] consider focused factory production as one of the lean practices under study while Vinodh et al. [19] identify the same as one of the areas for leanness improvement. Focused factory attempts to reduce the complexities of the manufacturing process by simplifying the organizational structure, reducing the numbers of products or processes, and minimizing the complexities of the physical constraints. Manufacturing systems have been led by technological developments [48] and since lean evolved from empirical experience of practitioners, it is necessary to monitor such technological developments [49] for its successful implementation. In this respect, adopting new process equipment or technologies have been considered as an effective lean practice [21, 50-51]. Based on the above arguments and evidence, it can be concluded that adopting new technologies and automation positively affects LM implementation.

Industry 4.0 aims for optimization of value chains by implementing an autonomously controlled and dynamic production. Enablers are the availability of real time information and networked systems. Instruments to reach this increased automation are CPS [12]. Equipped with microcontroller, actuators, sensors and a communication interface, CPS can work autonomously and interact with their production environment. Hence, Industry 4.0 is marked by highly developed automation and digitization processes and by the use of electronics and information technologies (IT) in manufacturing [9].The authors had carried out empirical research in the Indian manufacturing sector [52] to investigate the current state of the several factors influencing LM implementation. However, among the input factors, there was not much indication that automation and technological development positively affect successful LM implementation in the Indian manufacturing context. Introduction of new technology often involves an initial financial outlay, which many small and medium enterprises are not willing to undertake in the Indian context. This is a major limitation and therefore there is a dire need of implementing a system supporting automation which can be facilitated through Industry 4.0.

Industry 4.0 has already been started und will affect our life and the future business model expressly [28]. The term
Industry 4.0 describes a vision of future production and describes the increased integration of ICT into production. Production processes in LM are in comparison to other kinds of organization more standardized, more transparent and reduced to essential work and hence, they support the installation of Industry 4.0 solutions. Therefore, Industry 4.0 can complement Lean Production to match future requirements [12].

The Indian manufacturing companies are facing considerable challenges because of recent environmental, societal, economic and technological developments. To meet these challenges the manufacturing companies need capabilities for managing the entire value-chain in an agile and responsive manner. Indian firms require virtual and physical structures that allow for close cooperation and rapid adaption along the lifecycle from innovation and design to production and distribution. Hence, there needs to be a change in attitude and approach in the Indian manufacturing sector to be globally competitive in the future. Industry 4.0 will pivot the LM process by automating through CPS and building a highly flexible design and production model of customized and smart products and services, with real-time interactions between people, products and devices during the production process.

\section{CONCLUSION}

This work aims to explore how the fourth industrial revolution, referred to as Industry 4.0, can strategize lean in the Indian manufacturing context. Industry 4.0 needs to be integrated in LM not only for optimization of value chains but also for responding to customer demands for tailored products. The pull principle of production planning in LM eventually begins with the last link in the supply chain, the final customer of the product. By enabling the merger of digital and physical workflows, CPS will enable transmitting point-of-sale transactions and orders down the supply chain, thereby facilitating the Indian manufacturing firms to keep their design and production in line with the final demand. By utilizing advanced information analytics, networked machines will be able to perform more collaboratively and efficiently. When the physical production steps are accompanied by computer based processes, inventories and non-value adding activities will automatically be reduced throughout the chain, thus promoting a much leaner system. With recent developments that have resulted in higher availability and affordability of sensors, data acquisition systems and computer networks, it will be feasible for more manufacturing firms to move towards implementing high-tech methodologies to remain competitive in today's global market. This will definitely accelerate the shift of Industry 4.0 from concept to reality. Yet, since the integration of Industry 4.0 solutions is generally connected with advanced technology and high initial investments, in practice it will be lucrative where new solutions add value to users and reduce cost over a reasonable period of time, and where simple methods of LM are not completely fulfilling today's requirements. 


\section{REFERENCES}

[1] H. Lasi, P. Fettke, H. G. Kemper, T. Feld, and M. Hoffmann, "Industry 4.0", Business \& Information Systems Engineering, Vol. 6, No. 4, pp. 239-242, 2014.

[2] Encyclopedia Britannica website. [Online] Available at: https://www.britannica.com/event/Industrial-Revolution, 2004

[3] K. Zhou, T. Liu, and L. Zhou, "Industry 4.0: Towards future industrial opportunities and challenges", in 12th IEEE International Conference on Fuzzy Systems and Knowledge Discovery(FSKD 2015), Zhangjiajie, China, pp. 2147-2152.

[4] J. Qin, Y. Liu, and R. Grosvenor, "A categorical framework of manufacturing for industry 4.0 and beyond", Procedia CIRP, Vol. 52, pp. 173-178, 2016.

[5] T. Netland, "Industry 4.0: What about lean?", Lean Management Journal-LMJ, Vol. 5, No. 2, pp. 22-23, 2015.

[6] R. Schmidt, M. Möhring, R. C., Härting, C. Reichstein, P. Neumaier, and P. Jozinović, "Industry 4.0-potentials for creating smart products: empirical research results", in International Conference on Business Information Systems (BIS 2015), pp. 16-27, 2015.

[7] J. F. Krafcik, "Triumph of the lean production system", MIT Sloan Management Review, Vol. 30, No. 1, pp. 41-52, 1988.

[8] A. Sanders, C. Elangeswaran, and J. Wulfsberg, "Industry 4.0 implies lean manufacturing: research activities in industry 4.0 function as enablers for lean manufacturing", Journal of Industrial Engineering and Management, Vol. 9, No. 3, pp. 811-833, 2016

[9] Y. Lu, "Industry 4.0: a survey on technologies, applications and open research issues", Journal of Industrial Information Integration, Vol. 6, pp. 1-10, 2017.

[10] F. Almada-Lobo, "The Industry 4.0 revolution and the future of manufacturing execution systems (MES)", Journal of Innovation Management, Vol. 3, No.4, pp. 16-21, 2016.

[11] E. D. Arnheiter, and J. Maleyeff, "The integration of lean management and Six Sigma", The TQM magazine, Vol. 17, No. 1, pp. $5-18,2005$.

[12] D. Kolberg, and D. Zühlke, "Lean automation enabled by industry 4.0 technologies", IFAC-PapersOnLine, Vol. 48, No. 3, pp. 1870-1875, 2015.

[13] A. Susilawati, J. Tan, D. Bell andM. Sarwar, "Fuzzy logic based method to measure degree of lean activity in manufacturing industry", Journal of Manufacturing Systems, Vol. 34, pp. 1-11, 2015.

[14] M. D. Al-Tahat, and I. S. Jalham, "A structural equation model and a statistical investigation of lean-based quality and productivity improvement", Journal of Intelligent Manufacturing, Vol. 26 No. 3, pp. $571-583,2015$.

[15] J. P. Womack, D. T. Jones, D. Roos, and D. S. Carpenter, The machine that changed the world, Rawson Associates, New York: Macmillan Publishing Company, 1990.

[16] J. P. Womack, and D. T. Jones, Lean Thinking: Banish Waste and Create Wealth in Your Corporation, New York: Free Press, 2003.

[17] T. Bendell, "A review and comparison of six sigma and the lean organizations", The TQM magazine, Vol. 18, No. 3, pp. 255-262, 2006.

[18] M. Alsmadi, A. Almani, and R. Jerisat, "A comparative analysis of Lean practices and performance in the UK manufacturing and service sector firms", Total Quality Management \& Business Excellence, Vol. 23, No. 3-4, pp. 381-396, 2012.

[19] S. Vinodh, S. G. Gautham, and R. A. Ramiya, "Implementing lean sigma framework in an Indian automotive valves manufacturing organization: a case study", Production Planning \& Control, Vol. 22, No. 7, pp. 708-722, 2011.

[20] J. Bhamu, and K. Singh Sangwan, "Lean manufacturing: literature review and research issues", International Journal of Operations \& Production Management, Vol. 34, No.7, pp. 876-940, 2014.

[21] R. Shah, and P. T. Ward, "Lean manufacturing: context, practice bundles, and performance", Journal of Operations Management, Vol. 21, No. 2, pp. 129-149, 2003.

[22] R. Shah, A. Chandrasekaran, K. Linderman, "In pursuit of implementation patterns: The context of lean and Six Sigma", International Journal of Production Research, Vol. 46, No. 23, pp. 6679-6699, 2008.
[23] V. Kajdan, "Bumpy road to lean enterprise", Total Quality Management, Vol. 19, Nos. 1-2, pp. 91-99, 2008.

[24] R. Chavez, W. Yu, M. Jacobs, B. Fynes, F. Wiengarten, and A. Lecuna, "Internal lean practices and performance: The role of technological turbulence", International Journal of Production Economics, Vol. 160, pp. 157-171, 2015.

[25] H. Kagermann, W. Wahlster, and J. Helbig, "Recommendations for implementing the strategic initiative INDUSTRIE 4.0", Final report of the Industrie 4.0 Working Group, acatech - National Academy of Science and Engineering, 2013.

[26] T. Stock, and G. Seliger, "Opportunities of sustainable manufacturing in industry 4.0",Procedia CIRP 40, pp. 536-541, 2016.

[27] F. Shrouf, J. Ordieres, and G. Miragliotta, "Smart factories in Industry 4.0: A review of the concept and of energy management approached in production based on the Internet of Things paradigm", in IEEE International Conference on Industrial Engineering and Engineering Management (IEEM 2014), pp. 697-701, 2014.

[28] N. Jazdi, "Cyber physical systems in the context of Industry 4.0", in IEEE International Conference on Automation, Quality and Testing, Robotics, pp. 1-4, 2014.

[29] B. Mrugalska, and M. K. Wyrwicka, "Towards lean production in industry 4.0”, Procedia Engineering, Vol. 182, pp. 466-473, 2017.

[30] J. Lee, B. Bagheri, and H. A. Kao, "A cyber-physical systems architecture for industry 4.0-based manufacturing systems", Manufacturing Letters, Vol. 3, pp. 18-23, 2015.

[31] J. Schlechtendahl, M. Keinert, F. Kretschmer, A. Lechler, and A.Verl, "Making existing production systems Industry 4.0-ready", Production Engineering, Vol. 9, No. 1, pp. 143-148, 2015.

[32] B. Wang, J. Zhao, Z. Wan, J. Ma, H. Li, and J. Ma, "Lean Intelligent Production System and Value Stream Practice", in DEStech Transactions on Economics, Business and Management, 3rd International Conference on Economics and Management (ICEM 2016), pp. 1-6, 2016

[33] T. Wagner, C. Herrmann, and S. Thiede, "Industry 4.0 impacts on lean production systems", Procedia CIRP, Vol. 63, pp. 125-131, 2017.

[34] A. Schumacher, S. Erol, and W. Sihn, "A maturity model for assessing industry 4.0 readiness and maturity of manufacturing enterprises", Procedia CIRP, Vol. 52, pp. 161-166, 2016.

[35] V. Roblek, M. Meško, and A. Krapež, "A complex view of industry 4.0", SAGE Open, Vol. 6, No. 2, pp. 1-11, 2016

[36] D. Ivanov, A. Dolgui, B. Sokolov, F. Werner, and M. Ivanova, "A dynamic model and an algorithm for short-term supply chain scheduling in the smart factory industry 4.0" International Journal of Production Research, Vol. 54, No. 2, pp. 386-402, 2016.

[37] M. Rüßmann, M. Lorenz, P. Gerbert, M. Waldner, J. Justus, P. Engel, and M. Harnisch, "Industry 4.0: The future of productivity and growth in manufacturing industries", Boston Consulting Group, Vol. 9,No. 1, pp. 54-89, 2015.

[38] C. Liu, and X. Xu, "Cyber-physical Machine Tool: The Era of Machine Tool 4.0", Procedia CIRP, Vol. 63, pp. 70-75, 2017.

[39] G. Kube, and T. Rinn, "Industry 4.0: The next revolution in the industrial sector",ZGK International, Vol. 67, No. 11, pp. 30-32, 2014.

[40] F. Baena, A. Guarin, J. Mora, J. Sauza, and S. Retat, "Learning Factory: The Path to Industry 4.0", Procedia Manufacturing, Vol. 9, pp. 73-80, 2017.

[41] F. Long, P. Zeiler, and B. Bertsche, "Modelling the production systems in industry 4.0 and their availability with high-level Petri nets", IFAC-PapersOnLine, Vol. 49, No. 12, pp. 145-150, 2016.

[42] H. Meissner, R. Ilsen, and J. C. Aurich, "Analysis of control architectures in the context of Industry 4.0", Procedia CIRP, Vol. 62, pp. 165-169, 2017.

[43] C. Faller, and D. Feldmüller, "Industry 4.0 learning factory for regional SMEs", Procedia CIRP, Vol. 32, pp. 88-91, 2015.

[44] S. So, and H. Sun, "An extension of IDT in examining the relationship between electronic-enabled supply chain integration and the adoption of lean production", International Journal of Production Research, Vol. 49, No. 2, pp. 447-466, 2011.

[45] F. A. Abdulmalek, J. Rajgopal, and K. L. Needy, "A classification scheme for the process industry to guide the implementation of lean", Engineering Management Journal, Vol. 18, No. 2, pp. 15-25, 2006. 
[46] S. M. Zahraee, "A survey on lean manufacturing implementation in a selected manufacturing industry in Iran", International Journal of Lean Six Sigma, Vol. 7, No. 2, pp. 136-148, 2016.

[47] Pullan, T. T., Bhasi, M., Madhu, G. "Decision support tool for lean product and process development. Production Planning \& Control Vol. 24, No. 6, pp. 449-464, 2013.

[48] M. Houshmand, and B. Jamshidnezhad, "An extended model of design process of lean production systems by means of process variables", Robotics and Computer-Integrated Manufacturing, Vol. 22, No. 1, pp. 1-16, 2006.

[49] M. Hoss, and C. S. ten Caten, "Lean schools of thought", International Journal of Production Research, Vol. 51, No. 11, pp. 3270-3282, 2013.
[50] M. E. Bayou, and A. De Korvin, "Measuring the leanness of manufacturing systems: a case study of Ford Motor Company and General Motors", Journal of Engineering and Technology Management, Vol. 25, No. 4, pp. 287-304, 2008.

[51] M. Eswaramoorthi, G. R. Kathiresan, P. S. S. Prasad, and P. V. Mohanram, "A survey on lean practices in Indian machine tool industries", The International Journal of Advanced Manufacturing Technology, Vol. 52, Nos. 9-12, pp. 1091-1101, 2011.

[52] P. Basu, I. Ghosh, and P. K. Dan, "Structural equation modelling based empirical analysis of technical issues for lean manufacturing implementation in the Indian context" in 7th IEEE International Conference on Industrial Technology and Management (ICITM 2018), pp. 57-61, 2018. 